\title{
A GLOBÁLIS KAPITALIZMUS „SZENT CSALÁD”-JA. KRITIKAI ÉSZREVÉTELEK KIERKEGAARD NYOMÁN
}

\author{
KOCZISZKY ÉVA
}

\begin{abstract}
The "Holy Family" of Global Capitalism. Critical observations after Kierkegaard From a contemporary point of view the essay investigates the role, which the concept of family is playing in Christian thought. Starting from Kierkegaard's Either/ Or through the monastic idea of Agamben, it re-reads some relevant passages of both the Old and the New Testaments. We aim to prove that family and marriage are not synonyms but rather antonyms full of tension as they continuously relate to each other. There is not one single heavenly idea of family in the Bible, not even the often-mentioned Trinity. This identification may be nothing else but an exegetical distortion based on the autocratic position of the church in a medieval society getting ready for Capitalism.
\end{abstract}

\section{KIERKEGAARD VAGY-VAGYÁTÓL A GENEZISHEZ}

Søren Kierkegaard Vagy-vagy filozófiai elmélkedésének A betüvel jelzett esztéta szerzője egy eksztatikus tirádában fejezi ki kétségbeesését a házasság intézményét illetően: „Házasodj meg, meg fogod bánni; ne házasodj meg, azt is meg fogod bánni; házasodj vagy ne házasodj, mindkettőt meg fogod bánni; vagy megházasodsz, vagy nem, mindkettőt megbánod." $\mathrm{S}$ erre, mint ismeretes, B, az etikus szerző, aki polgári foglalkozására nézve egyébként „jogtanácsos”, csak azt tudja replikázni, hogy „a házasság az élet esztétikája”.²

A Vagy-vagy gondolatrendszerén belül három stádiuma van az egyén szubjektummá válásának, annak a folyamatnak, hogy a személy önmaga lesz. Ez egyszersmind három létformája a szeretet, a szerelem megélésének. Az első a szeretet esztétikai megélése, ez az erotikus stádium, alanya a csábító, paradigmatikus figurája

\footnotetext{
${ }^{1}$ Søren Kierkegaard: Vagy-vagy, Budapest, Gondolat, 1978, 53 .

${ }^{2}$ Uo. 570.
} 
Don Juan, illetve pontosabban Mozart operájának főhőse, Don Giovanni. A házasság mint az emberileg lehetséges legbensőségesebb szeretet-kapcsolat az exisztencia második, úgynevezett etikai stádiumához tartozik, ennek lényege, hogy a szerelem nem keres minden adódó tárgyban kielégülést, hanem választ, választja az egyetlen másikat. A második stádium hőse a férj, aki kedvesével együtt választja a szerelmet és a hűséget. A harmadik stádium az esztétikai és az etikai vagy-vagyán felülemelkedve a vallási, hőse a hit lovagja. Bár lehet családos vagy egyedülálló, ez nem számít, mert végső soron egyedül van Istennel életének döntő pillanataiban, akárcsak Ábrahám, amikor az ígéret gyermekét feláldozni indult. A vallásos stádium szerelme a megismert, magát kinyilatkozó Isten iránti abszolút szeretet.

Ismeretes, hogy ezen a gondolatrendszeren belül nincs átlépés az etikaiból a vallásiba, nemcsak az etikai és vallási, azaz az emberi és az isteni „törvény” szükségszerü kollíziója miatt, hanem mert a jó ember, a családban relatív boldogságát megtaláló polgár habitusa, a rezignáció, és ez ellene hat a vallási felé történő elmozdulásnak. Ezzel szemben átléphet az esztétikai egzisztencia, a libertinus, az élvhajhász, a modern „party” ember, tehetnénk hozzá, amennyiben eljut a végtelen kétségbeesés állapotába, ahová egyébként az esztétikai életvitel szükségképpen vezet.

Kierkegaard jeles magyar olvasói közül senki, például Heller Ágnes sem, vetette fel azt a kérdést, hogy az etikaihoz tartozó házasság kierkegaard-i relativizálása miként kapcsolódhat az újszövetségi kereszténységhez, hogy vajon nem keresztényietlen-e azt gondolni, hogy a házasság és főleg a család nem abszolút, örök érték, és „szentségének” katolikus hagyománya nem biblikus? Vajon ellentmond-e mindezzel Kierkegaard a bibliai hagyománynak is, vagy inkább csak kora protestáns és katolikus teológiájának, melynek közös sajátsága az, hogy a családban a Szentháromság földi leképeződését látják?

\section{A HÁZASSÁG KERESZTÉNY TALÁLMÁNY, A CSALÁD NEM}

A Vagy-vagy etikus férj alakja hivatkozik arra a mára talán már elhomályosult tényre, hogy a házasság mint olyan voltaképpen keresztény találmány, amelyet a maga teljes eszmeiségében sem az ótestamentumi zsidóság, sem a pogányság nem ismert. Azért, érvel B., mert a nemek közti különbség nem volt sem a zsidóságban, sem a pogányságban olyan mélyen reflektált, s ezért a szerelem sem bontakozhatott ki a maga abszolút, önmagáért való érvényével. Ami az ótestamentumi zsidóságot illeti, tehetjük hozzá B. érveléséhez, a többnejűség eleve ellentmond a házasság metafizikus igényü szövetségének, és - Kierkegaard nyomvonalán maradva - Salamon mitikus számú „ezer” felesége nem egy hü férjet, sokkal inkább a mozar- 
ti opera Don Giovannijának ugyancsak mitikus számmal kifejezett „ezerhárom” spanyolországi kedvesét juttathatja az eszünkbe. A filozófus etikusa azonban nem veti fel a kérdést, hogy vajon azonos-e vagy egymástól megkülönböztetendő-e a házasság és a család? Ebben egyébként követi Hegelt, aki szerint az ótestamentumi zsidóság a családra nem volt képes, holott saját érvelésébe az illett volna, hogy a házasságra nem volt képes. Söt, azt is hozzá kellene tennünk ehhez a történeti megkülönböztetéshez, hogy a kereszténység is csak lassan érleli ki, elsőként talán csak az individuális szerelemnek a trubadúrok költészetében bemutatott kultuszával azt, amit nő és férfi örök, testi-lelki szellemi egyesülésének nevezünk.

A házasság és a család történetileg rendkívül laza és változékony fogalmainak tisztázása nem feladatunk, ${ }^{3}$ de e fogalmak használatához tanulságos visszanyúlni a Genezishez. Ismeretes, hogy a Genezis kétszer és kétféleképpen beszél az ember nővé és férfivá való teremtéséről. De vajon miért, vajon puszta ismétlésről van-e szó?

Az első passzus a 1,26-28:

„És monda Isten: Teremtsünk embert a mi képünkre és hasonlatosságunkra; és uralkodjék a tenger halain, az ég madarain, a barmokon, mind az egész földön, és a földön csúszó-mászó mindenféle állatokon. Teremté tehát az Isten az embert az ő képére, Isten képére teremté őt: férfiúvá és asszonnyá teremté őket. És megáldá Isten őket, és monda nékik Isten: Szaporodjatok és sokasodjatok, és töltsétek be a földet és hajtsátok birodalmatok alá; és uralkodjatok a tenger halain, az ég madarain, és a földön csúszó-mászó mindenféle állatokon." ${ }^{4}$

Ebben az elbeszélésben a nő és a férfi még nem mint individuum szerepel, egyiküknek sincs neve.

Ezzel szemben a Genezis 2,21-25, amely Évának Ádámból való teremtését beszéli el, már két személy megalkotásáról szól, akik az első néven nevezett emberek:

„Bocsáta tehát az Úr Isten mély álmot Ádámra, és ez elaluvék. Akkor kivőn egyet annak oldalbordái közül, és hússal tölté be annak helyét. És alkotá az Úr Isten azt az oldalbordát, amelyet kivett vala az emberből, asszonynyá, és vivé az emberhez. És monda az ember: Ez már csontomból való csont, és testemből való test: ez asszony-

3 Tanulmányok sora mutatja be, hogy az, amit ma „családon” értünk, nem létezett az ősegyház idejében. A „család” többnyire a családfo, férfi alá tartozó egész házanépet jelentette, amelyhez hozzátartoztak a távolabbi rokonok, a rabszolgák stb. Lásd Carolyn Osiek: The Family on Early Christianity: values revisited, Catholic Biblical Quarterly 58, 1-24.

${ }^{4}$ A Bibliát itt és az egész tanulmányban Károli Gáspár fordításában idézem. Revideált szöveg. 
embernek neveztessék, mert emberből vétetett. Annakokáért elhagyja a férfiú az ő atyját és az ő anyját, és ragaszkodik feleségéhez: és lesznek egy testté. Valának pedig mindketten mezítelenek, az ember és az ő felesége, és nem szégyenlik vala.”

Az első elbeszélés illeszkedik az élővilág egészének megteremtésébe, a férfi és a nő megáldatik a szaporodás, a sokasodás képességével, éppúgy, amiképpen elözőleg más élőlények is ezzel megáldattak:

„Pezsdüljenek a vizek élő állatok nyüzsgésétől; és madarak repdessenek a föld felett, az ég mennyezetének színén. És teremté Isten a nagy vízi állatokat, és mindazokat a csúszó-mászó állatokat, amelyek nyüzsögnek a vizekben az ő nemök szerint, és mindenféle szárnyas repdesőt az ő neme szerint. És látá Isten, hogy jó. És megáldá azokat Isten, mondván: Szaporodjatok, és sokasodjatok, és töltsétek be a tenger vizeit; a madár is sokasodjék a földön” (Gen 1,20-22).

A szaporodás, a sokasodás isteni törvényszerüség, természeti törvény, mely az egész teremtett világra érvényes, $s$ az emberi nemre nézve is mindig érvényes marad, az egész bünbeesett emberiségre. Mint Dávid és Jeremiás paradox módon mondja, hogy egyfelől minden ember bünösen jön a világra, mégis mindenkit Isten hív elő az anyaméhből. „Ímé én vétekben fogantattam, és bünben melengetett engem az anyám” (Zsolt 51,7). „Mielőtt megformáltalak az anyaméhben, már ismertelek” (Jer 1,5).

Ezzel szemben a második elbeszélés, nem anonim hím- és nőneműek termékeny összekapcsolásáról tudósít: a szereplő az első emberpár, Ádám és Éva, akik az általánosan elfogadott magyarázat szerint a házasság intézményét mutatják be. Eszerint a házasságban működik egy olyan egyesülés, ami több, mint természeti, ami több, mint valami célnak (például a faj fennmaradásának) a szolgálata, valami, ami abszolút, s ami „transzcendens”. Fontos azonban észrevenni azt is, hogy ebben a passzusban a szöveg profetikus beszédmódban szól, hiszen Ádámra és Évára semmiképpen sem értelmes az a kitétel, hogy elhagyják apjukat és anyjukat, és így lesznek az egymásért élésben egyesülve egy testté. Ez a kitétel a maga teljességében csak a keresztény házasság sajátsága lesz.

Az első, a természet általános törvényszerüségei közé helyezett ember-teremtés elbeszélése és a második, sajátosan két individuumra vonatkoztatott ember-teremtés története, Ádám és Éva megalkotása között hasonló hangsúlyeltolódást észlelhetünk, mint a család és a házasság fogalmai között. Az első természetes szinten jelöli ki az ember részvételét az általános élet körforgásában, a második viszont a természetes vérségi kötelékektől való eloldódást s egy magasabb rendű szeretetbeli egység választását és nem múlandó igenlését jelöli ki.

A házasság és a család tehát már a Genezisben is sokkal kevésbé szinonimája egymásnak, mint inkább dinamikus, egymásba folyamatosan átcsapó ellentétek. 
Azzal, hogy a férfi és a nő társat, férjet, feleséget választ magának, a választás szabad aktusával egyszersmind ki is lép természetes közegéből, a családból, azt elhagyja. Jézus megismétli a Genezis szavait: „Ezért a férfi elhagyja atyját és anyját és ragaszkodik az ő feleségéhez, és a kettő egy testté lesz" (Mt 19,5), hogy azután ök ketten is egy családot hozzanak létre, melyet majd a gyermekeknek kell elhagyniuk, hogy immár ők is a természetes család kötelékeiből kilépve szabadon válaszszanak maguknak társat. Ebben az értelemben a házasság maga egyszerre családellenes és családalapító tett.

A házasság és család folyamatosan egymásba forduló ellentétpárját összetartja továbbá az is, hogy a Biblia mindkét emberi viszonylatot tragikusnak mutatja be. Az első család a maga egészében egy tragédia: Kierkegaard Vagy-vagyában említés történik egy rézmetszetről, mely Káint ábrázolja, aki megölte fivérét, Ábelt. A háttérben pedig Ádám és Éva láthatók. A metszeten egy felirat is található: prima caedes, primi parentes, primus luctus - az elsö gyilkosság, az elsö szülők, az elsö gyász. ${ }^{5}$ A család alapját képező szaporodás, az úgynevezett „gyermekáldás” a Biblia szerint tehát éppúgy lehet áldás forrása, mint ennek ellentéte. Egyfelől az apák és anyák természetes, a természet által adatott sajátsága az, hogy szeretik a gyermekeiket, gondoskodnak róluk. A Lukács evangélium 11,11-13 szerint még a "gonosz", bünös életvitelü szülők is szeretettel gondoskodnak utódaikról:

„Ugyan melyik apa az közületek, aki a fiának követ ad, amikor az kenyeret kér, és kígyót ad, amikor az halat kér? (...) Ha azért Ti gonosz létetekre tudtok a fiaitoknak jó ajándékokat adni, mennyivel inkább ad a ti Mennyei Atyátok Szentlelket azoknak, akik kérik tőle." Másfelöl azonban, mint a fenti párhuzam is jelzi, csak abban az esetben nevezi a Biblia áldásnak a családot, ha a gyermekek fiakká növekedve megmaradnak a hitben. ${ }^{6}$

Nem sokkal jobb a helyzet a házassággal sem, éspedig nemcsak a többnejüséggé torzulása miatt, hanem amiatt is, hogy már a mózesi törvények megsemmisíthetőnek nyilvánították (5Móz 24,1). Ez az a bizonyos válólevél, mellyel a férfi - a bibliai lexikonok szerint (indoklás nélkül) - elbocsáthatja a feleségét. Az Evangéliumok ezt a gyakorlatot az emberi szív keménységének tett engedménnyel magyarázzák. Amiképpen az egyén kapcsolatainak törékenységét számos ótestamentumi történet bemutatja, hasonlóképpen törékenynek, sőt tragikusan végződőnek látjuk az ótestamentumi házasság mennyei mintáját is, Jahve szerelmi házasságát Izraellel. Végül Isten maga is válólevelet ad hütlen feleségének, Izraelnek (Ézs 50,1. Jer $3,8)$. Jézus ezt a válást siratja, mikor Jeruzsálem fölött sír, mert, mint Kierkegaard írja, a világ nem sok ilyen mérvű tragédiát látott.?

\footnotetext{
${ }^{5}$ Vagy-vagy, 614.

${ }^{6}$ Péld 23,24

7 Vagy-vagy, 869.
} 


\section{A „SZENT CSALÁD” TEOLÓGIÁJA}

A kierkegaard-i és az idézett kortárs filozófiában megfogalmazódó kritikai szemlélettel diametrális ellentétben él a mai kulturális átideologizálódott kereszténységben egy ideálkép a „szent család” eszméjéről, melyet „biblikusan” a Szentháromság hármasságával legitimálnak. A katolikus teológia mellett a protestáns írásmagyarázatban, sőt a neoprotestáns kisegyházakban is általánosan elterjedt az a felfogás, mely szerint a földi család egy mennyei család leképeződése. „Krisztus születésének első tanúi, a pásztorok, nemcsak a kisgyermek Jézust látták maguk elött, hanem egy kis családot, mely anyából, apából és az éppen megszületett gyermekből állt. Isten úgy kívánta magát nyilvánvalóvá tenni, hogy egy családba beleszületett. Ezért az emberi család Isten ikonjává vált! Isten maga mint Szentháromság létezik, azaz a szeretetnek a közössége, melynek közvetlen kifejeződése a család" - fejtegette akár éppen protestáns elődei nyomdokán XVI. Benedek is egy családnapon, de ugyanez elhangozhatott volna számos egyházi közösség szószékéről is. Amikor Benedek arról beszél, hogy Jézus egy „családba” születik bele, elfeledkezik arról, hogy ez a „család” semmiképpen nem hasonlított egy mai keresztény családhoz: Mária a jegyessége alatt vált várandóssá, amely a korabeli izraeli törvények szerint paráznaságot jelentett, hiszen ki hitte volna el neki, hogy a Szent Lélektől fogant? Anyaságát egyébként az Evangéliumok a hétköznapi értelemben vett anyasággal nem is azonosítják: Jézus maga sosem nevezi anyjának Máriát, hanem a güné, „asszony” tiszteletteli, de nem családi megszólítást használja (Jn 2,4; 19,26). A külső szemlélők és az evangelisták ugyan olykor használják Máriára az anya megjelölést is, de sokszor különös fordulatokkal, ami jelzi a zavart: nevezik például Jézus testvére, „Jakab anyjának”. Ezért voltaképpen meglepő, hogy még a magukat „bibliai” keresztényeknek tartó közösségek is, mint az Egyesült Âllamok presbiteriánus, baptista, sőt karizmatikus közösségei, a 19. század vége óta a Bibliát a családi értékek kézikönyvének tekintik, melyhez természetszerüleg tartozik egy még nagyobb „család”, a nemzet szinte szakrális értéke.

Ezek a teológiák a Szentháromság igen különös magyarázatával élnek. Eszerint az isteni három személy voltaképpen egy család lenne, amely szeretetközösségben él. Anélkül, hogy meg tudnánk határozni, hogy mi is valójában a Szentháromság, ami nyilvánvalóan lehetetlen feladat, meg tudjuk vizsgálni azt, hogy mi nem: nem apa-anya-gyermek viszonya, nem család, sőt az is kérdéses, hogy szeretetközösség lenne, mert a szeretet mindig feltételez egy abszolút, egy valóban más, tőlem független Másikat, míg ezt maga az Egy Isten három arccal eleve kizárja.

Csupán a forrásra történő visszautalásként hivatkozom Tertullianusra, aki legalábbis a hagyományozott szövegek szerint - elöször fogalmazta meg a trinitás lényegét, hogy ti. a Biblia istene egy, de három „maszkja”, három szerepe (latinul 
personája), azaz megnyilvánulási formája van. ${ }^{8}$ A persona szó kifejezés használata teljességgel kizárja azt, hogy három, mai értelemben vett „személyt” képzeljünk el. Mint a korábbi kutatásokra hivatkozó Hans Belting megjegyzi, a persona a latin nyelvben még csak nem is a személyiséggel szoros kapcsolatban álló arc megjelölésére szolgált - ez a facies volt -, hanem a színházi maszk latin neveként szolgált, s amely csak jóval a Szentháromság personáira való alkalmazás után, Boethius korában jelenti a személyt is. ${ }^{9} \mathrm{Az}$ Egy Isten tehát semmiképpen sem foglal magában egy egész családot, nem feltételez egymástól elválasztható személyeket, nem feltételezi a másikat, akire a szeretet irányulhatna.

A „szent család” teológiájának és társadalomtörténeti vonatkozásainak együttesét legutóbb például Albrecht Koschorke esszéje foglalta össze, amelynek lényeges tételeire jelen keretek között lehetetlen kitérni, ${ }^{10}$ ezért megelégszünk néhány utalással. A „szent család” eszmeiségének genezise visszanyúlik az Evangéliumok Mária képét radikálisan átalakító Mária-tisztelet kezdeteihez. Az antikvitásból fennmaradt pogány kultuszok befolyására az efezusi zsinat határozata (i. sz. 431) Máriát az „istenszülö" melléknévben részesíti, s ezzel - kiemelve őt a földi dimenzióból - már csak idő kérdése volt, hogy az Atya és a Fiú mellé kerüljön a mennybe. Az érett középkor során megerősödő Mária-kultuszhoz járult azután a házasság szentségének a 12. században bevezetett dogmája, mellyel az ideális feleség mintegy Mária földi tükörképévé vált, s ezzel együtt Józsefnek és az evangéliumi történetben betöltött szerepe is alapvetően megváltozott. A kezdetben komikus öregemberként megjelenő József alakja, aki nyilvánvalóan nem Jézus apja, a 12. században alapvető változáson megy keresztül. Ezt a változást jelzik Clairvaux-i Szent Bernát bolognai prédikációi, amelyekben Bernát hangsúlyozta, hogy Józsefnek, mint a Jézust szerető és nevelő apának, fö szerep jutott „a szent családban”, majd a képzőművészeti ábrázolások is azt sugallták, hogy mint a család anyagi biztonságának megteremtője, egyben ellátója, József egy kis deus faber.

A „szent család” képzőművészeti népszerüsége a 14. századra megerősödött, majd így vált a Szentháromság égi mintáját visszatükröző földi szent család (változó szereplős) háromsága a reneszánsz művészet egyik legkedveltebb témájává. Nem meglepő módon a reformáció is hozzájárult a mennyei trinitást tükröző „szent család”-nak a naturalizálódásához: Martin Luther a szellemi és testi egybekapcsolásával egyszerre szekularizálta Jézus családját és reszakrakralizálta a polgári családot. Ennek eredményeképpen ábrázolja Rembrandt (egyébként nagyszerü)

\footnotetext{
${ }^{8}$ Quintus Septimus Florens Tertullianus: Adversus Praxean. Gegen Praxean. Fontes Christiani 2. Folge, Bd. 34, Freiburg i. B., Herder, 2010, 108.

${ }^{9}$ Hans Belting: A hiteles kép. Képviták mint hitviták, Budapest, Atlantisz, 2009, 106-108.

${ }^{10}$ Albrecht Koschorke: Die Heilige Familie und ihre Folgen, Frankfurt am Main, Fischer, 2000.
} 
festménye egy németalföldi polgári család realista világát Szent családként (1633, München, Pinakothek).

Szekularizáció és célzatos reszakralizálás kettős eredményeképpen a polgári főleg kis- és nyárspolgári - család eszménye ma nem jelent mást, mint populista, álkonzervatív és jórészt cinikus hatalmi intézmények szlogenjét, amelyet egy kultúrát és gondolkodást félresöprő világkorszak szétbomlott szociális formációinak autoritatívan üzenni kíván.

\section{JÉZUS CSALÁDJA}

Jézusnak a családról szóló evangéliumi üzenetei ma is megosztottságot és vitát indikálnak. Erre reflektálva fontos leszögezni: Jézus nem volt soha érzéketlen a családi értékek iránt. A Máté 19,16-21-ben Jézus a gazdag ifuút megdicséri azért, hogy hite szerint megtartja a Jézus által említett erkölcsi parancsolatokat, melyek között szerepel az atya és anya iránti tisztelet is. Csakhogy ez nem elég, olvassuk a folytatásban: „Ha tökéletes akarsz lenni, menj el, add el vagyonodat, oszd szét a szegényeknek, és kincsed lesz a mennyben; aztán jöjj, és kövess engem." Vagyis: Add fel mindazt, ami a családodhoz, a vagyonodhoz, a szociális státuszodhoz köt, mert csak így követhetsz. Jézus beszédeinek egyik legjellemzőbb sajátsága, hogy a szociális formák és intézmények - állam, világi-hatalmi struktúrák, vallási hierarchiák - közül egyedül a házassági szövetséget emeli ki, s tekinti abszolútnak. A nő és férfi kapcsolatban megvalósuló, hit által munkálkodó szerelem ugyanis az egyetlen, amely kieszközli a valós életben gondolat és cselekvés egységét. A házasság ezért az egyetlen olyan metafora a Bibliában, melynek transzcendens vonatkozásai vannak: az Ószövetségben Jahve és Izrael szövetsége ez, az Újszövetségben pedig Jézus Krisztus a vőlegény, akinek menyasszonya a gyülekezet, a szentek közössége mint menyasszony említtetik. Ezzel együtt is az alábbi passzusok nem tesznek lényegi különbséget örökletes, vérségi, szociális és választott kapcsolatok között:

Lk 14,26: Ha valaki hozzám jön, és nem gyülöli meg atyját és anyját, feleségét és gyermekeit, fiútestvéreit és nőtestvéreit, sőt a saját életét is, nem lehet az én tanítványom.

Mt 10,35-37: Azért jöttem, hogy meghasonlást támasszak az ember és az ő atyja, a leány és az ő anyja, a meny és az ő napa között, és hogy az embernek ellensége legyen az ő házanépe. Aki jobban szereti atyját, vagy anyját, mint engem, nem méltó énhozzám, és aki jobban szereti fiát, vagy leányát, mint engem, nem méltó énhozzám. 
Mt 19,29: És mindenki, aki elhagyta a házait, a fiú- vagy nőtestvéreit, vagy atyját vagy anyját, feleségét vagy gyermekeit, vagy szántóföldjeit én érettem, száz annyit kap majd helyette, s (ráadásul) örök életet nyer örökségül.

Mt 8,21-22: Egy másik tanítványa pedig ezt mondta: Uram, engedd meg, hogy előbb elmenjek és eltemessem az atyámat. De Jézus ezt mondta: Kövess engem és hagyd, hogy a halottak temessék el a halottakat.

Mk 3,32-35: A körülötte ülő sokaságból megszólalt valaki: Íme a te anyád és testvéreid ott kinn keresnek téged. Ő azonban így felelt nekik: Ki az én anyám és kik az én testvéreim? Majd végigtekintett a körülötte ülőkön és így szólt: Íme az én anyám és az én testvéreim! Mert aki az az Isten akaratát cselekszi, az az én fiútestvérem, nőtestvérem és atyám.

Jézus hasonló tartalmú szavainak sorát még szaporíthatnánk. Mindegyik idézett vagy idézhető szöveghely világossá teszi: az általa hirdetett és meg is testesített királyság nem e világi, hanem egy radikálisan másik világ, amely megköveteli az egyéntől a gondolkodás, azaz elme és a szív teljes megújulását, s ebben az értelemben a felfüggesztését minden vallási, szociális és kulturális kötődésnek, legyenek azok még egyébként Jézus által is értékesnek tartottak, mint például a legközelebbiek szeretete és a békességben élés. Jézus hangsúlyozza, hogy az ő követése szükségképpen konfliktusokhoz vezet, mert nem simul egyetlen világkorszak gondolkodásmódjához sem, az nem lesz képes Övele tartani. A keresztény ember „új teremtés”, szellemtől született exisztencia, és az eszerinti életvitel szükségszerüen magában hordozza a családdal, a hagyományokkal, a szociális környezettel való feszültségeket. A keresztény élet nem „american way of life”, hanem folyamatos kaland, eseménydús utazás Isten országába, amely során fokozatosan alakulnak át az igei mércékhez igazodva az elmében, a habitusban és az életvitelben azok a vallási, szociális, sőt kulturális kódolások, melyeket a mindenkori környezet diktál.

Azáltal, hogy annak a hitnek, amelyre Jézus a tanítványait rá kívánja vezetni, leglényegesebb újdonsága az, hogy immár nincs közvetítő Isten és ember között, sem a törvény, sem a hagyomány nem közvetít többé, hanem minden egyes hívő személyesen kapcsolatban áll Istennel, egyedül a kereszténység teheti a szeretet parancsává az eloldódást, az öröklött, a fennálló társadalmi kötelék eloldását, s képes felszámolni a társadalmi, szociális, etnikai, nembeli egyenlőtlenségeket.

Ez a szeretet- és szerelemeszmény hatja át az európai drámairodalom egyik legismertebb gyöngyszemét, Shakespeare Romeó és Júliáját, melynek híres erkélyjelenetében „Romeó és Júlia kategorikusan kijelentik, hogy gyülölik és eldobják saját családnevüket (Montague, Capulet) és így, mint Slavoj Žižek írja, »lekapcsolják« 
magukat partikuláris (családi) társadalmi meghatározottságaikról, akkor vajon nem a legnyilvánvalóbb példáját adják annak, hogy a "gyülöld meg saját szüleidet « felszólításban maga a szerelem fejeződik ki?"” ${ }^{1}$ A kereszténység ezért alapjaiban demokratikus és forradalmi, mert az egyén „közvetlenül részese lehet az univerzalitásnak, tekintet nélkül arra, hogy milyen helyet tölt be a globális társadalmi rendben”. Sőt, maga Krisztus és Pál apostol is úgy jellemzi az agapé parancsát, hogy ez eloldoz minket mindentől, ami beleszületettségként, „szocio-szimbolikus hálózatként" fogságban tarthat. A keresztény szeretet tökéletes szabadsága annyira egyenlőségelvü, hogy nem tesz különbséget úr és szolga, férfi és nő, görög és zsidó, sőt ellenség és barát között sem, amennyiben még az ellenség szeretetének parancsát is magában foglalja.

\section{TÖVISEK ÉS BOGÁNCSOK}

Jézus Krisztus beszédei nyomán Pál apostol leveleiben nem találunk példát arra, hogy Pál a családnak kiemelt vallási jelentőséget tulajdonított volna. Sőt, a páli levelek abban a vonatkozásban még tovább mennek, hogy a házasságot is többnyire, az Efezusiakhoz írt levél passzusának kivételével, gyakorlati szempontok mentén vizsgálja. A megházasodást Pál sem tekinti az egyetlen lehetséges életmintának. Az apostol hivatkozhatna ebben a vonatkozásban a Mt 19,10-11-re, melyben Jézus azt jelenti ki, hogy nem minden embernek való a házasság. Vannak olyanok, akik valamiért képtelenek erre, akár testi, akár lelki okokból, vagy pedig szellemi-vallási választásuk folytán:
„Mondom nektek, hogy aki elbocsátja feleségét - a paráznaság esetét kivéve -, és mást vesz feleségül, az házasságtörő. Erre így szóltak hozzá tanítványai: »Ha ilyen a férfi helyzete az asszonnyal, akkor nem jó megházasodni.« Ỏ azonban így válaszolt: »Nem mindenki képes elfogadni ezt a beszédet, csak az, akinek megadatott.»"

Míg a férfi tanítványok ebben a beszélgetésben azon háborognak, hogy nem jó megházasodni, ha nem szabad elválni, egy másik, női perspektíva villan fel Jézusnak a samáriai asszonnyal folytatott beszélgetésében. A János 4,16-20 elbeszélése szerint annak az asszonynak már öt férje volt, és az a hatodik, akivel éppen élt, már nem is volt a férje. Egy keserü, nehéz élet pillanatképe ez: talán meghalt az asszony mindegyik korábbi férje? Vagy sorra válólevelet adtak neki? Eldobták maguktól az asszonyt, mint egy használt tárgyat? Akármi is történt pontosan, ezek a házassá-

${ }^{11}$ Uo. 219. 
gok végül egy törvényen kívüli élethez, sőt sejthetően a prostitúcióhoz vezettek („a mostani nem férjed"). Jézus azonban nem elveti az asszonyt, hanem helyreállítja az életét azzal, hogy kijelenti neki: Ö az, akit a nő várt, a Messiás: „Én vagyok az, aki veled beszélek".

Pál apostol szerint nem való mindenkinek a házasság, mert „kinek-kinek tulajdon kegyelmi ajándéka van Istentől, egynek így, másnak pedig úgy” (1Kor 7,7). A házasság mint intézmény azonban védelmet jelent a szexuális szabadosságok ellen, ezeknél feltétlenül jobb: 1Kor7,2: „A paráznaság elkerülése céljából minden férfinak legyen tulajdon felesége és minden asszonynak tulajdon férje.” Egyébként azonban túlburjánozhat benne a pusztán materiális, gyakorlatiasan szociális dolgokkal való foglalatoskodás: „Azt szeretném pedig, hogy gond ne terheljen titeket. Aki nem házas, azzal törődik, az Úré, hogyan tessék az Úrnak. Aki viszont

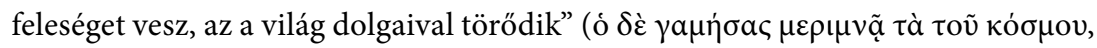
1 Kor 7,32-33).

A „világ gondjai” már a magvető jézusi példázatában olyannak mutatkoztak, mint a bogáncs: megfojtják a Krisztusban elnyert új élet felnövekedő magját, a hitben érő személyiséget. Ez lehet a családos ember sorsa is, ahelyett hogy „gondtalanul” élne, ahogyan Pál kívánja neki: $\Theta \dot{\varepsilon} \lambda \omega \delta \dot{\varepsilon}$ ú $\mu \tilde{a} \varsigma$ à $\mu \varepsilon \rho i ́ \mu v o v \varsigma$ cĩval. Ami pedig a gyermeknemzést illeti, ezt, mint Isten rendelte célt egyáltalán nem említi. Erre vonatkozólag kizárólag egy többértelmü, a bünbeesettség állapotára utaló passzust találunk a Timótheushoz írt első levélben, amely a gyermekszülést próbatételnek fogja fel: eszerint az asszony megtartatik a gyermekszüléskor, amennyiben hittel teljes és szent életü (1Tim 2,15). Az Efézusiakhoz írt levele végén pedig a családban megőrzendő rendet hangoztatja gyermekek és szülők, urak és szolgák viszonylatában (Ef 6,1-10). Ezekben a passzusokban Pál családfelfogása nem is áll olyan távol Immanuel Kantétól, amennyiben a családot jogok és kötelességek rendszerének tekinti, amelynek szem előtt tartása elengedhetetlen a szociális viszonyok rendezettségéhez és békéjéhez. A „világgal élés” azonban Pál számára mindig is temporális, sőt másodlagos, szükséges és mégis zárójelbe teendő:

„Ezentúl azért akiknek feleségük van, úgy legyenek, mintha nem volna. És akik sírnak, mintha nem sírnának, és akik örülnek, mintha nem örülnének. Akik vásárolnak, mintha nem maguknak szereznének. És akik a világgal élnek, mintha nem élnének vele" (1Kor7, 29-31).

A páli passzus érvényességét azzal szokás az egyházi prédikációkban korlátozni, hogy mindezt Pál csak ezért írta, mert (tévesen) azt hitte, hogy az utolsó időkben élünk. De hát nem mindig az utolsó időben élünk-e, nem mindig a mi saját 
pillanatunkat, azt a „most”-ot szalasztjuk el?"2 A partikulárisért, a pillanatnyi önérdekért vajon nem az univerzálist és az örök értékűt szalasztjuk-e el? Pál másutt ugyanezt a tanácsát úgy fejti ki, hogy leszögezi: Krisztusban nincs zsidó és görög, nincs nő és férfi, és folytathatnánk a sort: nincs apa és fiú, nincs nővér és fivér. Žižek ezt az univerzalizmust harcos formának nevezi, és így kommentálja: „Amikor Pál azt mondja, hogy a kereszténység szempontjából »nincs zsidó, sem görög, nincs férfi sem nö«, akkor ez nem azt jelenti, hogy az egész emberiség olyan lesz, mint egy nagy, boldog család, hanem azt, hogy van egy olyan választóvonal, ami keresztülmetszi a partikuláris identitásokat, és végső soron irrelevánssá teszi az egyéb különbségeket. »Nincs zsidó, sem görög, nincs férfi sem nő«, csak a „keresztények és a kereszténység ellenségei vannak!”.13

\section{A HIT ÁLTAL MUNKÁLKODÓ SZERETET VALLÁSA}

Az Újszövetség és némely (kortárs) filozófiai reflexiók tehát érintkeznek egymással a fenti gondolati keret metszetében: A család nem a Szentháromság földi képe és a kereszténység nem kalauz vagy bölcsességek tárháza a boldog hétköznapi élethez, sőt még az erényeshez sem. Az amerikai heideggeriánus filozófus John Caputo megjelentetett egy könyvet azzal a címmel, hogy Mit dekonstruálna Jézus, ha testileg közöttünk lenne? ${ }^{14}$ Bár Caputo „vallástalan vallás” koncepciója nem túl gazdag mélyreható kritikai vizsgálódásokban, ${ }^{15}$ azonban a kérdésfelvetése például szolgálhatna. A fentiek alapján megkockáztatom, hogy Jézus a kapitalizmusban végletekig deformálódott, ámde annál cukrosabbá és áhítatosabbá vált családeszmét is lebontaná, sőt egyenesen lerombolná, amiképpen a kétezer évvel ezelötti kijelentéseivel ezt már meg is tette. Hasonlóképpen járna a személyére vonatkozólag a Szentháromság teológiai család-metaforája is, amely az „american way of life” ke-

${ }^{12}$ Jézus példázata a nagy vacsoráról ugyancsak erről szól: „Egy ember nagy vacsorát készített, és sok vendéget hívott. Amikor eljött a vacsora ideje, elküldte szolgáját, s azt üzente a meghívottaknak: Jertek, mert már minden készen. Ekkor mindnyájan sorra elkezdték magukat mentegetni: Az első azt üzente neki: Szántóföldet vettem, és ki kell mennem, hogy megnézzem. Kérlek, fogadd el a mentségemet. És a másik azt mondta neki: Öt iga ökröt vettem, és elmegyek, hogy kipróbáljam. Kérlek, fogadd el a mentségemet! Megint másik így szólt: Feleséget vettem, és ezért nem mehetek" (Lk 14,16-20).

${ }^{13}$ Slavoj Žižek: „Egyszer mint tragédia, másszor mint bohózat. Szeptember 11. tragédiájától a pénzügyi összeomlás bohózatáig", Eszmélet 84. sz. Melléklet, 39. Budapest, 2009.

${ }^{14}$ John D. Caputo: What would Jesus Deconstruct? Good News of Postmedernity for the Church, Baker Academic Publications, 2007.

${ }^{15}$ Keresztények jobban megbarátkozhatnak Hans Conrad Zander biblikusabb, humoros könyvével. Lásd Konrad Zander: Der erste Single: Jesus, der Familienfeind, Gütersloh, Gütersloher Verlagshaus, 2010. 
reszténységében a hívőben az éretlen gyermek képzetét kelti, s ezzel egyszersmind infantilizálja is őt. Sőt, egy még rosszabb esetben alárendeli a „bárányt” multiplikálódott, egymásnak is ellentmondó földi apáknak, legyenek azok gyóntató atyák, pápák, gyülekezeti vezetők vagy egyéb bölcs tekintélyek, akik visszaélve a hit bizalmi állapotához egyébként hozzátartozó gyermekséggel, bölcsebbnél bölcsebb élettanácsokat osztogatnak, sőt nem is ritkán perverzül kihasználják a kiskorúsítottakat. ${ }^{16}$ Ez a teológia kétségkívül a reformáció azon örökségét folytatja, mely szerint, mint Calvin fogalmazott, minden atyában „valami isteni” rejlik, ${ }^{17}$ illetve mint Luther fogalmazott a Katekizmusában: a szülők tekintélyének bibliai elismerése kiterjesztendő minden világi felelősségre, a societas, illetve az állam minden tisztségviselöjére, akiket szintén atyaként kell tisztelni. ${ }^{18} \mathrm{Az}$ e világi szent családban uralkodó házirend ezzel egyszersmind a fennálló államrend őrzője.

Mindezzel a protestáns gondolkodás ezen ága egy teljesen elvilágiasított, elmaterializált, valóságidegen, a mai hétköznapi ember vélekedéséhez hasonított istenképet közvetít a Biblia Istenéről, azt az emberi atyasághoz igazítva. ${ }^{19}$ A tradicionális családnak a 19. század végétől megállíthatatlanul tartó széthullását Thomas Manntól kezdve Chestertonig a modern kapitalizmus számlájára szokás írni. Az elváltak, az egyedülállók, a spermabankok és béranyák jelenkori társadalmában a nosztalgiának pedig már semmi értelme. Sokkal inkább érdemes kutatni azokat az előremutató lehetőségeket, amelyek a benső élet és a komoly érzelmek álszentségének leleplezésében rejlik, s ezen az ideológiakritikai alapon egy megújult evangéliumi látásmóddal munkálkodni is az Istennek szentelt egyéni és a közösségi élet sokszerüségén. Szignifikáns, hogy az utóbbi évtizedek politikai pesszimizmusának korában számos filozófiai és vallástudományi kísérlet nyúl vissza a szerzetességhez, mint mutatis mutandis a 21. századba áthelyezhető közösségi életformához. Giorgio Agamben szerint a szerzetességben megvalósult valami, ami egyébként teljességgel lehetetlen: egy nem törvényekre, hanem szabályokra épített közösség

\footnotetext{
${ }^{16}$ Hivatkozom a katolikus egyház mellett például az amerikai baptista közösséget is alapjaiban megrengető - rendkívül magas számú - pedofil zaklatásokra. Az egyházakban denominációtól függetlenül szinte általános gyakorlattá lett szexuális molesztálás és erőszak véleményem szerint nem müködhetne a hamis tekintéllyel történő sok évszázados visszaélés híján, és mint Ratzinger legutóbbi, sok vihart kavaró cikkében kifejtette, az egyházban uralkodó „istentelenség" nélkül.

${ }^{17}$ Koschorke: 151.

${ }^{18}$ Idézi az eredeti német szövegből Koschorke: 154 .

${ }^{19}$ Slavoj Žižek szerint ezt tette Ferenc pápa is, amikor önkényesen korrekciót rendelt el a Miatyánk szövegén azzal az érveléssel, hogy Isten soha senkit nem kísért. Lásd Slavoj Žižek: Wie ein Dieb bei Tageslicht. Macht im Zeitalter des posthumanen Kapitalismus, Frankfurt am Main, Fischer, 2019, 269.
} 
müködtetése, amelynek középpontjában az a tudat munkál, hogy az életünket nem birtokoljuk, hanem csak használjuk, azért, hogy azt Istennek szentelhessük. ${ }^{20}$

A „család” mint vallási metafora kritikája nem kívánja továbbá cáfolni, hogy a kereszténység a hit által hatékony szeretet vallása. Ezért is használja az Üjszövetség a hívo „szentek” és Krisztus kapcsolatára a menyasszony és a vőlegény jegyességének metaforáját. Ezzel egyszersmind rávilágít arra is, hogy a keresztényi szeretet nem velünkszületett adottság, hanem a keresztség „feltámadásában” részesült és abban megalapozott személy új életének esszenciája és cselekvő ereje. „Szabadnak lenni annyit tesz, mint szeretetben élni. Szeretetben élni pedig azonos azzal, hogy Isten igazságában élünk." ${ }^{21}$

${ }^{20}$ Giorgio Agamben: The Highest Poverty: Monastic Rules and Form-of-Life, California, Stanford Univ. Press, 2013.

${ }^{21}$ Dietrich Bonhoeffer: Werke, Bd. 11, Gütersloh, Gütersloher Verlagshaus, 462. 